\title{
Planning for Rift Valley fever virus: use of geographical information systems to estimate the human health threat of white-tailed deer (Odocoileus virginianus)-related transmission
}

\author{
Sravan Kakani, A. Desirée LaBeaud, Charles H. King \\ Center for Global Health and Diseases, Case Western Reserve University, School of Medicine, 10900 \\ Euclid Avenue, Cleveland, OH 44106-7286, USA
}

\begin{abstract}
Rift Valley fever (RVF) virus is a mosquito-borne phlebovirus of the Bunyaviridae family that causes frequent outbreaks of severe animal and human disease in sub-Saharan Africa, Egypt and the Arabian Peninsula. Based on its many known competent vectors, its potential for transmission via aerosolization, and its progressive spread from East Africa to neighbouring regions, RVF is considered a high-priority, emerging health threat for humans, livestock and wildlife in all parts of the world. Introduction of West Nile virus to North America has shown the potential for "exotic" viral pathogens to become embedded in local ecological systems. While RVF is known to infect and amplify within domestic livestock, such as taurine cattle, sheep and goats, if RVF virus is accidentally or intentionally introduced into North America, an important unknown factor will be the role of local wildlife in the maintenance or propagation of virus transmission. We examined the potential impact of RVF transmission via white-tailed deer (Odocoileus virginianus) in a typical north-eastern United States urban-suburban landscape, where livestock are rare but where these potentially susceptible, ungulate wildlife are highly abundant. Model results, based on overlap of mosquito, human and projected deer densities, indicate that a significant proportion $\left(497 / 1186 \mathrm{~km}^{2}\right.$, i.e. $\left.42 \%\right)$ of the urban and peri-urban landscape could be affected by RVF transmission during the late summer months. Deer population losses, either by intervention for herd reduction or by RVF-related mortality, would substantially reduce these likely transmission zones to $53.1 \mathrm{~km}^{2}$, i.e. by $89 \%$.
\end{abstract}

Keywords: haemorrhagic fevers, viral prevention and control, bioterrorism, Rift Valley fever, deer, Culicidae, USA.

\section{Introduction}

In considering the events of the past decade, the introduction of "exotic" pathogens to North America, whether accidental or through bioterrorism, now appears sufficiently plausible to merit regional planning for prevention and/or containment of biodefense threats. One particular concern is the introduction and accelerated spread of highly pathogenic viruses, such as Rift Valley fever (RVF)

Corresponding author:

Charles H. King

Center for Global Health and Diseases, WRB 4126

CWRU, School of Medicine

10900 Euclid Avenue, Cleveland, OH, 44106-7286, USA

Tel. +1 216368 3667; Fax + 12163684825

E-mail: chk@cwru.edu virus, that could incapacitate or kill large numbers of people, while also potentially decimating local stocks of susceptible farm animals (Weaver and Reisen, 2010).

RVF virus is a member of the Bunyaviridae family of insect-borne RNA viruses (Flick and Bouloy, 2005) that was first described in sub-Saharan Africa in the Rift Valley province of Kenya (Daubney et al., 1931). RVF is primarily a zoonosis, i.e. an infectious disease transmitted from animals to humans (Bengis et al., 2004). Epidemics typically occur during periodic RVF epizootics that grow to involve sympatric transmission to humans (Ksiazek et al., 1989; Logan et al., 1992).

In order to predict the likely impact of such viral threats to public health, one must account not only for human risk factors and the characteristic insect 
vectors, but also the local amplifying animal reservoirs that could effectively facilitate local transmission. Outside of livestock raising areas, wild ungulate fauna may prove to be the most common North American animal reservoir for an emerging virus such as RVF virus, similar to the role played by wild avifauna after the introduction of West Nile (WN) virus into the eastern USA in 1999 (Brault, 2009).

Based on the assumption that abundant wild ungulates, such as the common white-tailed deer (Odocoileus virginianus), are poised to become the most important amplifying hosts for RVF in nonagricultural areas of the north-eastern USA, this paper discusses the zoonotic and vector abundance factors likely to determine the areas of highest risk for an outbreak of RVF within urban and periurban settings of a typical mid-western North American area, e.g. Cuyahoga county, located in the north-eastern part of the state of Ohio (LaBeaud et al., 2008). Our objective is to use data on host, vector and ungulate wildlife distribution to map out areas at high risk for RVF transmission. Prioritization in public health interventions to high risk areas will be necessary to restrict RVF transmission most effectively over the long term. At present, our projections are purely hypothetical. However, we feel that it is appropriate now to examine the available data that could guide early intervention and elimination efforts, and perhaps prevent permanent establishment of this dangerous pathogen within local ecosystems.

\section{Materials and methods}

\section{Assumptions for analysis}

The overlap of human, mosquito and deer habitat in a typical North American urban and peri-urban setting was examined. Our estimates, based partially on recent experience with the introduction of WN virus to the study location (Mandalakas et al., 2005; LaBeaud et al., 2008), assume that an ungulateamplified arbovirus such as RVF virus (Weaver and Reisen, 2010) is introduced into the area and trans- mits successfully among local insect and mammalian fauna. Our geographical information system (GIS) projected risk-maps assume that transmission risk is density dependent, and that local Aedes or Culex spp. will provide the necessary bridge vectors to mediate local animal-to-animal and animal-tohuman transmission during RVF epizootics and epidemics (Muturi et al., 2008; Turell et al., 2008).

\section{Study area characteristics}

Cuyahoga county (2008 mid-year population estimated at $1,283,925$ ) is $1,186 \mathrm{~km}^{2}$ in size, located in north-eastern Ohio, USA. In terms of climate, Cuyahoga is located in the humid continental temperate zone, with overall mean temperature of $10^{\circ} \mathrm{C}$, and mean maximum temperature of $28^{\circ} \mathrm{C}$ in July and mean minimum temperature of $-7.3{ }^{\circ} \mathrm{C}$ in January. The county includes the city of Cleveland, its older inner-ring suburbs, and many of its newer second-ring suburbs, as well as several large regional parks, and industrial and agricultural areas. Mosquito breeding season mirrors the observed growing season of 156 to 194 days, from May to October. More than half of the $980 \mathrm{~mm}$ average annual rainfall occurs during the growing season, with the wettest month being June $(99 \mathrm{~mm})$ (National Climate Data Center for Cleveland, Ohio, available at http://www.ncdc.noaa.gov). There are an average of 127 days per year in which the temperature drops to $0{ }^{\circ} \mathrm{C}$ or lower. In $2006,23 \%(27,653 \mathrm{ha})$ of the county was forested (USDA Forest Service database, available at http://fia.fs.fed.us/tools-data/), providing good habitat for deer, although $98 \%(116,420 \mathrm{ha})$ is still classified among the "urban" categories of landuse (residential, commericial, open). One percent or less of county land is crop land, and there are $359 \mathrm{~km}$ of major roads (a measure of habitat fractionation) transecting the area (Iverson and Iverson, 1999). In terms of agricultural livestock, there are an estimated 100-600 sheep, 1,000 cattle, and 100-300 pigs present in the county area (USDA National Agricultural Statistical Service, available at http://www.nass. usda.gov/). 


\section{Human density}

Location specific human density data were based on 2000 census tract-level data for human residence, provided by the US Census Bureau (http://www.census.gov/geo/www/tiger/).

\section{Mosquito density}

Mosquito trap data were obtained from the Cuyahoga County Board of Health. Standard gravid traps and CDC miniature light traps were placed overnight at geocoded locations across the county during each transmission season (May-October) from 2002 through 2006. In 2002, 660 traps were placed on a non-systematic basis in areas of suspected WN virus transmission (based on reports of suspected cases of human WN neurological disease (WNND), of observed bird mortality or of high mosquito abundance). From 2003 onwards, repeated systematic trapping was performed using rotating coverage over a grid of 119 defined geographic locations distributed across the county at $\sim 3.2 \mathrm{~km}$ intervals (LaBeaud et al., 2008).

\section{Deer density}

The potential animal reservoir of RVF considered in this analysis was O. virginianus. Although white-tailed deer are not presently known to transmit RVF, they represent a numerous standing stock of potentially susceptible, large ungulates that could serve to amplify RVF transmission. For the present study, white-tailed deer census data were obtained from the Public Works Department of the City of Solon, Ohio, in south-east Cuyahoga county (no other municipalities had such information). Remote sensing via aerial infrared surveillance provided point location data for deer (Naugle et al., 1996) These data were gathered in the fall of 2004 and again in the fall of 2005 , after the loss of canopy leaves within the predominantly deciduous forest areas. During the 2004-2005, a deer control programme was imple- mented by the city, with significant reductions in local deer density.

Next, a land-use map was used to subdivide Solon area into residential, other urban, open (agricultural and rangeland), forested, water, wetland and transitional land use areas according to the classification codes provided by United States Geological Survey (USGS). In order to characterize ecological subregions within Solon city's landscape that were relatively homogeneous for deer abundance, we used spatially constrained agglomerative clustering of deer-density in adjacent landuse polygons (Fortin and Drapeau, 1995; implemented in BoundarySeer software, BioMedWare; Ann Arbor, MI, USA) to identify separate lowlevel and high-level deer abundance areas (see Fig. 1 ). We subsequently used these subregion boundaries, characterized as a "Solon city center" region and a "Solon periphery" region, in order to establish representative deer densities for each type of land use in central and more peripheral urban and suburban settings (see Table 1 for deer densities and Fig. 2 for land use distributions). For the county-wide projections reported in the results section and Figures 4 and 5, other areas of Cuyahoga county were assigned their probable deer density values by extrapolation of the Solon data, based on their respective land use ratios and their central vs. peripheral location in the county. Ultimately, the data for the central region of Solon was used as a proxy for habitat in the inner ring suburbs of Cleveland, which is more highly urbanized and made up of older neighbourhoods, while the Solon peripheral region approximated habitat in the outer ring of Cleveland suburbs, i.e. at the eastern, southern and western borders of Cuyahoga county, with younger housing developments and more open and forested areas. The operative inner- and outer-ring designations could also be based on contiguity with City of Cleveland proper (LaBeaud et al., 2008); those municipalities adjacent to Cleveland were characterized as "inner-ring” while those not touching Cleveland were most often defined as "outer-ring". 

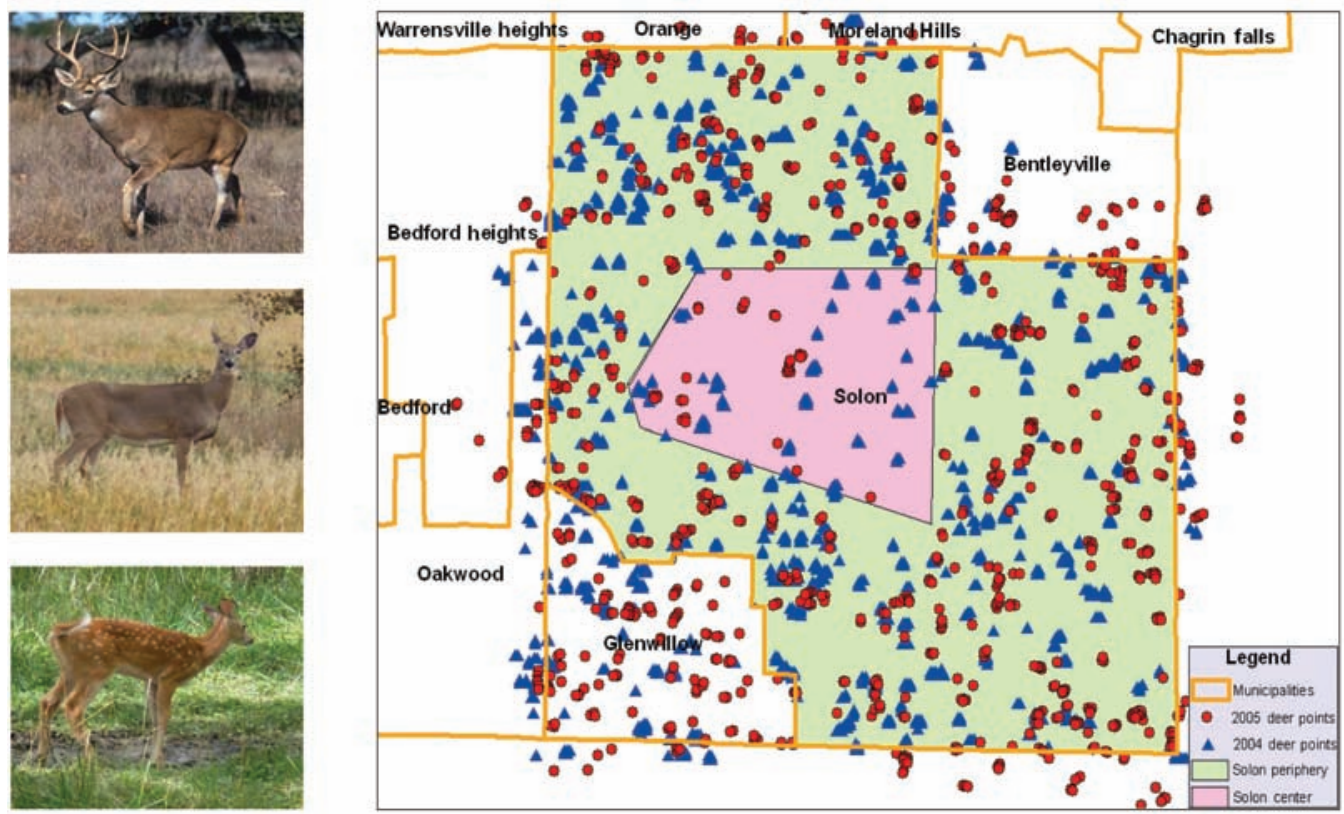

Fig. 1. Left-top panel, male or buck white-tailed deer; left-center panel, female or doe; left-bottom panel, infant deer or fawn; right panel, City of Solon, Ohio and surrounding municipalities in the south-eastern section of Cuyahoga county, Ohio. Map indicates central and peripheral deer census regions in Solon, with the 2004 and 2005 remotely-sensed (aerial infrared) deer detection points. Photo credits: buck photo, Scott Bauer, US Dept. of Agriculture (public domain); doe photo, Julia Adamson; fawn photo, Jonathunder (with permission under Wikimedia Creative Commons Attribution license).

\section{Solon center}

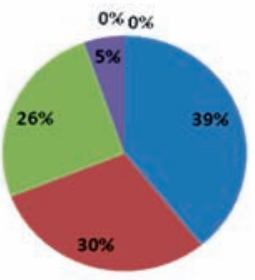

\section{Cuyahoga inner-ring suburbs}

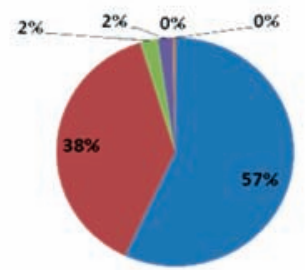

\section{Solon periphery}
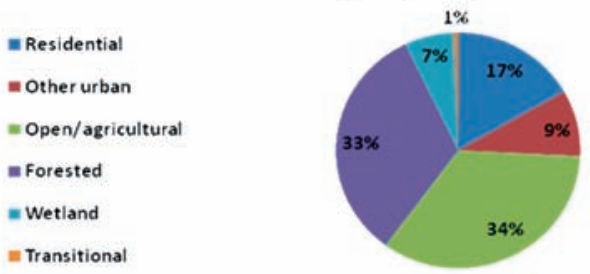

\section{Cuyahoga outer-ring suburbs}

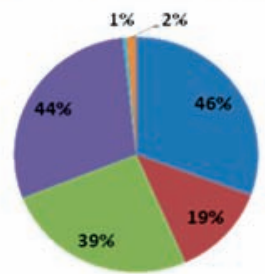

Fig. 2. Comparison of land use characteristics of Cuyahoga county inner-ring and outer-ring suburbs (lower panels) with land use within corresponding central and peripheral sectors of the City of Solon, Ohio (upper panels), which were used as the basis for the inner-ring and outer-ring suburbs' deer density projections. 


\section{GIS analysis}

ArcGIS version 9.2 (ESRI; Redlands, CA, USA) was used for all analyses in this project. An arbitrary GIS shape file was created for Cuyahoga county to divide its area into equivalent grid squares (Ruiz et al., 2004). Human census tract data for 2000 was spatially joined with the grid squares in order to tally human population per grid square, and population density was calculated for each square. Aedes vexans and Culex spp. per-trap-night density numbers were first derived from georeferenced location shapefiles (point data) of pre-control mosquito collections from $2002(\mathrm{~N}=436)$. Because of the unbalanced sampling system used in 2002, our analysis grouped all georeferenced mosquito collections for June-July (225 records) and August-September (211 records) periods to increase the number of observations available for grid each area. Smoothed area estimates of local mosquito density in each time period were then developed by applying a kernel density estimation across the analysis grid (Fig. 3). Four distant corner points were added to the attribute table for each time period in order to extend the density calculation up to county borders. Observed density per $\mathrm{km}^{2}$ was then calculated, and 10 ordinal groups of relative mosquito density were created using quantiles, and joined to the existing grid.

Grid-based rasters were also created for the projected values of 2004 inner-ring deer density, 2004 outerring deer density, 2005 inner-ring deer density, 2005 outer-ring deer density (see under Deer density; described above), based on land-use characteristics within each grid and on its "central" versus "peripheral" status. These density rasters each included 10 quantiles and were analysed as deciles. The raster calculator (spatial analyst tool) was then used to select areas of overlap (intersection) within the county for which all three variables had high values, i.e. above the $50^{\text {th }}$ percentile value for each variable. We assumed that greatest local abundance of susceptible reservoir, vector and human hosts would provide the greatest risk of local transmission among deer and would also result in the greatest number of human cases (LaBeaud et al., 2008), and developed our maps of projected risk (Figs. 4 and 5) accordingly.

\section{Results}

\section{Deer density across differing landscapes}

Results of the 2004 and 2005 Solon city aerial deer census indicated an average of 21.4 animals per $\mathrm{km}^{2}$ (55.4 deer/mi $\left.{ }^{2}\right)$ before introduction of a culling
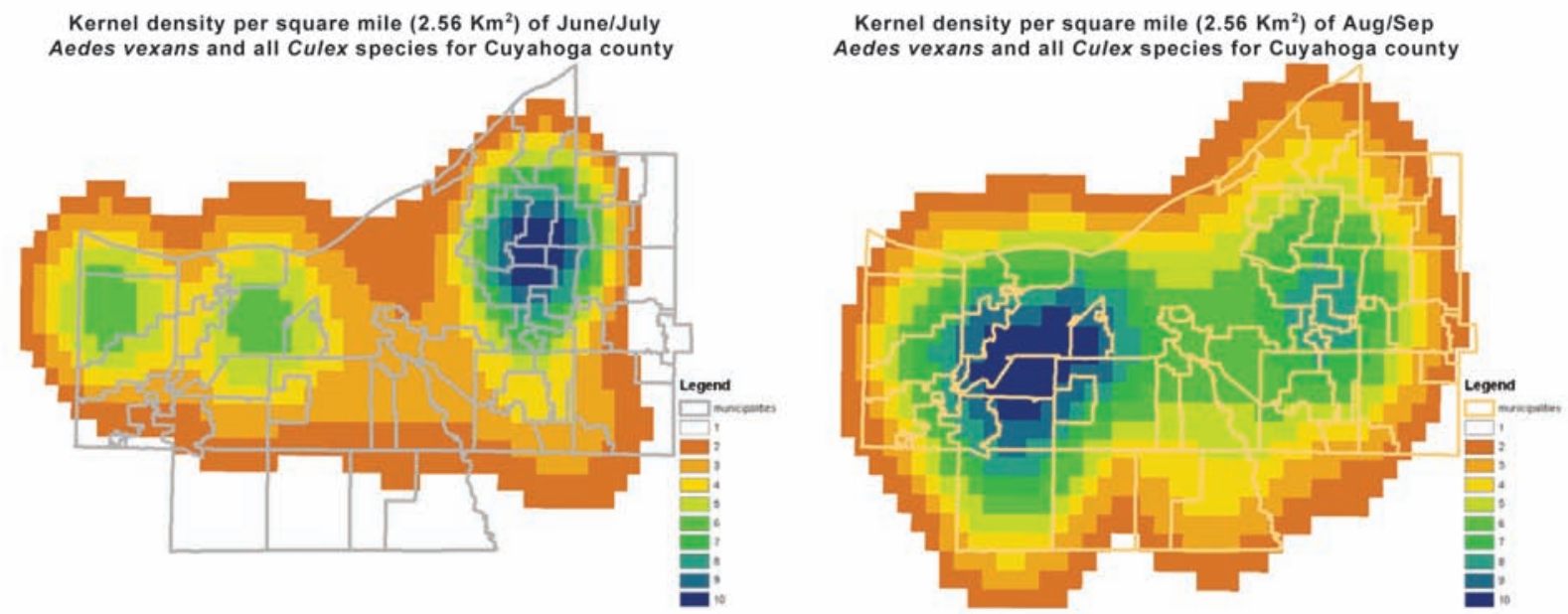

Fig. 3. Culex spp. and Aedes vexans mosquito densities per square mile $\left(2.56 \mathrm{~km}^{2}\right)$ by Kernel estimation in June/July (left panel) and August/September (right panel) based on mosquito trap data of the Cuyahoga County Board of Health for the years 20022006. 
programme. Following removal of animals in fallwinter 2004-2005, average density was reduced by $42 \%$ to $12 / \mathrm{km}^{2}\left(32 / \mathrm{mi}^{2}\right)$. Figure 1 shows images of white-tailed deer, and indicates the Solon city boundaries and those of neighbouring municipalities, along with observed deer locations during the fall 2004 and 2005 deer censuses. Table 1 shows the deer densities by land use category within the designated center and peripheral regions of the city in the pre- and post-control periods. It indicates a differential impact by location (central versus peripheral) of the culling programme on remaining population density in 2005 (69\% reduction versus 39\% reduction, respectively).

\section{Mosquito density estimates}

Figure 3 indicates Kernel density estimates of relative mosquito abundance across the Cuyahoga county area. There was higher abundance of mosquitoes in the eastern inner-ring suburbs during the June-July period, with an apparent shift of highest abundance to the western and south-western suburbs later during the August-September period.

Intersection of human, deer and mosquito abundance

Based on GIS-based spatial analysis of the available human and mosquito data, and the expected local deer abundance based on component land use as extrapolated from the observed Solon city data (see above), the areas of the county with highest potential risk of density-dependent arbovirus transmission among deer and between deer and humans are shown in Figures 4 and 5. Based on these estimates, we would expect the greatest number of human cases to occur in the areas marked in blue in the inner- and outer-ring suburbs as indicated during the June-July and August-September time periods. Without deer control, substantially larger areas are involved in August and September $\left(497 \mathrm{~km}^{2}\right.$ in August-September, compared to $135 \mathrm{~km}^{2}$ in JuneJuly). Figures 4 and 5 also indicate the potential impact of reducing deer herd size, with a moderate, post-control reduction of projected transmission areas in the June-July period $\left(135 \mathrm{~km}^{2}\right.$ reduced to $53 \mathrm{~km}^{2}$, i.e. $61 \%$ reduction with lower deer density), and a more substantial reduction for AugustSeptember $\left(497 \mathrm{~km}^{2}\right.$ to $53 \mathrm{~km}^{2}$, i.e. $89 \%$ reduction in high deer-mosquito-human overlap areas after countywide deer control).

\section{Discussion}

Our results suggest that white-tailed deer populations could serve as an effective vertebrate reservoir for mosquito-borne infection, including arboviruses, even in a "highly developed" peri-urban setting in North America. The resurgence of the North

Table 1. Observed white-tail deer density per $\mathrm{km}^{2}$ for Solon, Ohio. Columns indicate values for the city's central area and for its periphery, before (2004) and after (2005) implementation of deer population control.

\begin{tabular}{|c|c|c|c|c|}
\hline \multirow[b]{2}{*}{ Land use category } & \multicolumn{4}{|c|}{ Deer density per square $\mathrm{km}^{2}$} \\
\hline & 2004 Center & 2005 Center & 2004 Periphery & 2005 Periphery \\
\hline Residential & 14 & 2 & 27 & 19 \\
\hline Other urban & 15 & 5 & 24 & 14 \\
\hline Open & 7 & 4 & 21 & 13 \\
\hline Forested & 16 & 12 & 25 & 12 \\
\hline Wetland & $\mathrm{n} / \mathrm{a}$ & $\mathrm{n} / \mathrm{a}$ & 13 & 24 \\
\hline Transitional & $\mathrm{n} / \mathrm{a}$ & $\mathrm{n} / \mathrm{a}$ & 31 & 15 \\
\hline $\begin{array}{l}\text { Overall deer density for } \\
\text { Solon subareas }\end{array}$ & 12 & 4 & 23 & 14 \\
\hline
\end{tabular}



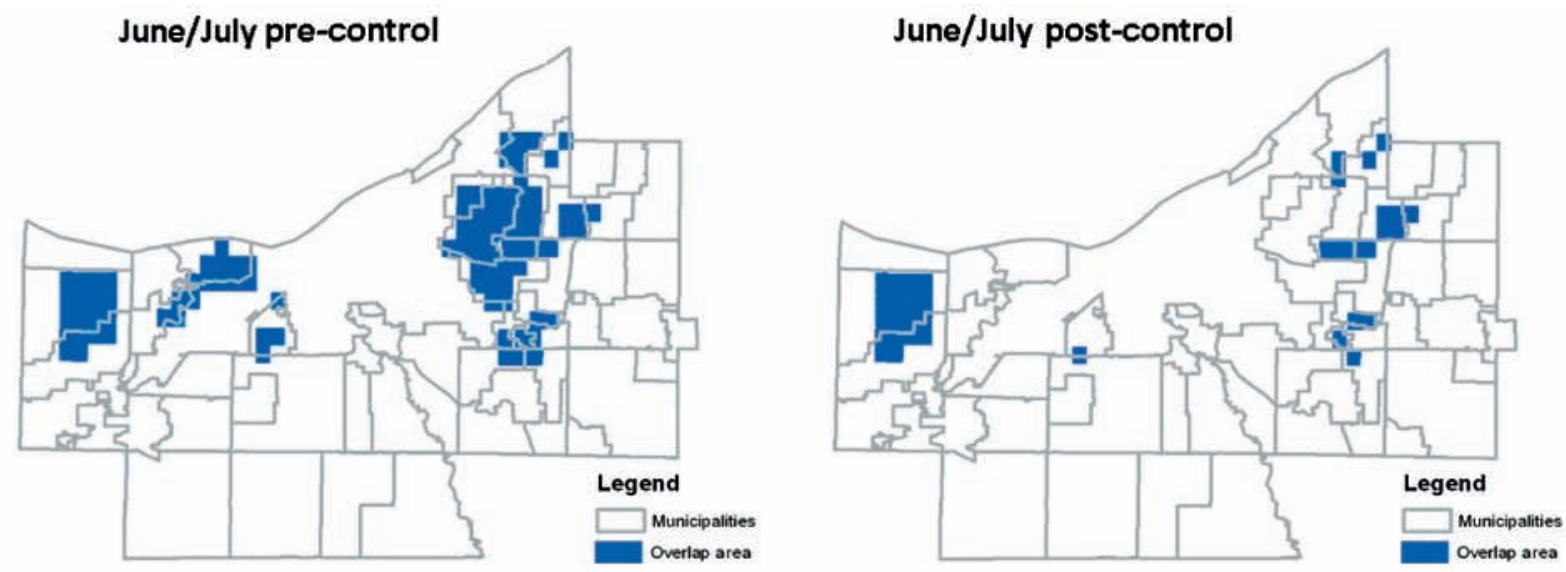

Fig. 4. Map of high density mosquito, high density human, and high density deer overlap in June/July, projecting deer density with (right panel) and without (left panel) implementation of deer population control.
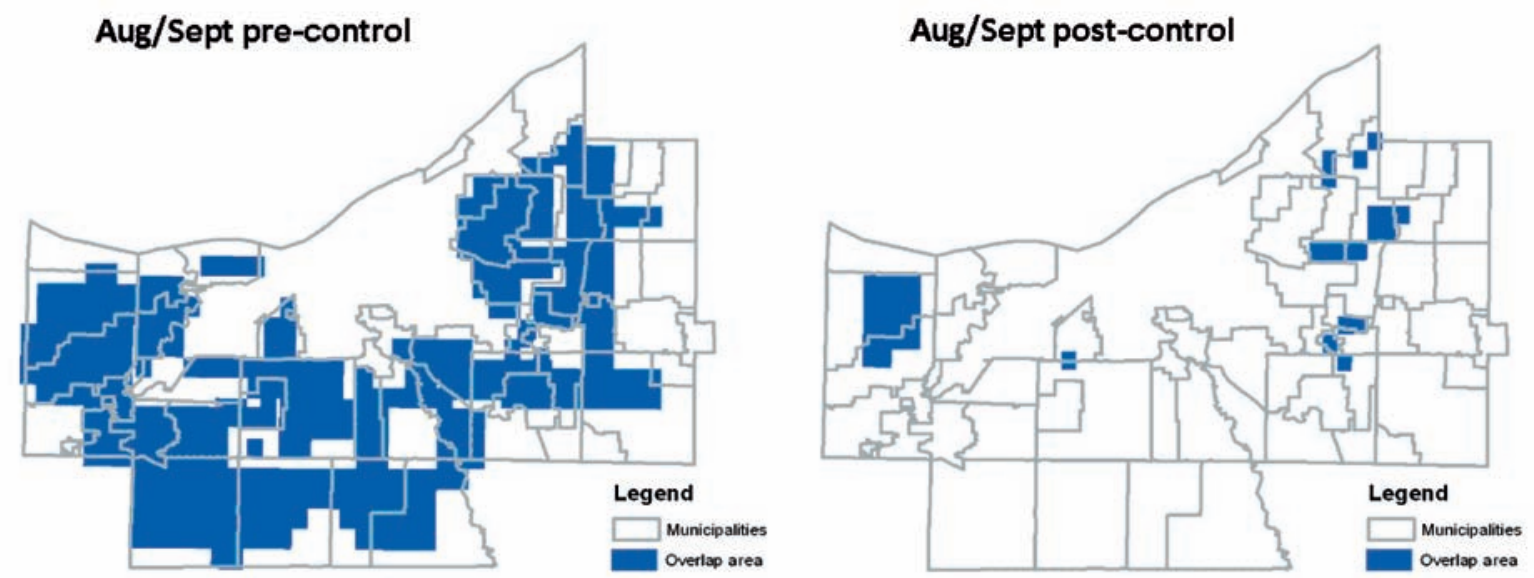

Fig. 5. Map of high density mosquito, high density human, and high density deer overlap in August/September, projecting deer density with (right panel) and without (left panel) implementation of deer population control.

American deer population, already linked to the spread of tick-borne pathogens Lyme borreliosis (Piesman, 2006), ehrlichiosis, and anaplasmosis (Manangan et al., 2007; Hoen et al., 2009), could also provide a extensive reservoir for transmission of an exotic mosquito-borne pathogen, such as RVF virus. White-tailed deer are a common source of mosquito blood meals. Recent blood-meal studies of Anopheles spp. and Aedes spp. in the north-eastern US (Apperson et al., 2004; Molaei et al., 2009a,b) indicate that deer are the source of at least half of the meals taken by these species. While in urban and peri-urban settings, Culex spp. favour birds for their blood meals, they remain opportunists, and at least 1:7 of their blood meals are taken from mammals, predominantly humans, in city areas (Hamer et al., 2009; Huang et al., 2009). In more suburban areas, $10-16 \%$ of Culex blood meals have been found to come from white-tailed deer (Apperson et al., 2004), indicating their strong potential as bridge vectors for deer-to-human arbovirus transmission in mixed urban and suburban areas.

Deer populations have dramatically increased in the north-eastern US over the last 50 years, as their 
preferred forest habitat has actually increased in this region over time. Reductions in open cropland, and increases in fractionated forested habitat have contributed to this trend. Fractionation of habitat has been linked to increased human arboviral disease in previous studies (LaBeaud et al., 2008). In the absence of natural predation, with the exception of human hunting, deer populations may reach 35 per $\mathrm{km}^{2}\left(90\right.$ per $\mathrm{mi}^{2}$ ) in some areas (Shafer-Nolan, 1997; O'Brien et al., 2006). Of note, the total forested area of Cuyahoga actually increased by $26 \%$ between 1991 and 2006 (USDA Forest Service database, available at http://fia.fs.fed.us/tools-data/), a period in which many crop areas were taken out of production pending suburban development (Stoll et al., 1991; Iverson and Iverson, 1999) and mixed use forested parkland was increased within the county (Shafer-Nolan, 1997). With this resurgence, whitetailed deer have become embedded wildlife as part of the county landscape, with the attendant risk of deer-borne zoonoses (O’Brien et al., 2006). The situation here is analogous to the return of the red fox in suburban areas of northern Europe, which has been associated with risk for introduction of sylvatic strains of rabies and echinococcosis within city limits (Deplazes et al., 2004).

White-tailed deer are currently known to be reservoirs for the mosquito-borne arboviruses Jamestown Canyon, Cache valley and Potosi viruses (Molaei et al., 2009a), and epizootic haemorrhagic disease virus (Allison et al., 2010), which are not presently considered to be pathogenic for humans. The question remains: will white-tailed deer provide a suitable amplifying wild reservoir for introduced "exotic" pathogens such as RVF virus? Though the virus has not been documented in the US, in 2000 it crossed the continental boundaries of Africa to extend into the Middle East (Balkhy and Memish, 2003). North American mosquitoes have been shown to be competent vectors for RVF virus in laboratory studies (Turell et al., 2008), and there is real concern about potential RVF spread to Europe and the Americas (Weaver and Reisen, 2010). RVF flares up within local ecosystems following heavy rains (Davies et al.,
1985; Linthicum et al., 1999) that permit its initial reservoir, floodwater Aedes spp. mosquitoes, to emerge and then infect nearby susceptible mammals (Linthicum et al., 1985). Later blooms of other competent vector mosquito species such as Culex perpetuate transmission during wet periods.

In Africa, susceptible wildlife and livestock are predominantly ruminant species, including cattle, sheep, goats, and including local wildlife such as African buffalo, lesser kudu, impala, kongoni, waterbuck and eland (Evans et al., 2008). In animals, RVF infection is frequently associated with haemorrhagic disease and high mortality, as well as high rates of fetal demise and miscarriage among pregnant females (Wilson et al., 1994; Woods et al., 2002). Humans may either acquire RVF virus through direct contact with infected animal tissues, by inhalation of aerosols of body fluids from infected animals, or via mosquito bites. In humans, RVF is most often self limited, resulting in a 4-7 day illness characterized by fevers, arthralgias and headaches (Kahlon et al., 2010). However, in approximately $10 \%$ of cases, acute RVF involves more severe pathology, including meningoencephalitis, uveitis and/or retinitis, while in 0.3 to $1 \%$ of cases, a fatal haemorrhagic fever develops (Laughlin, et al., 1979, Al-Hazmi et al., 2003). Among emerging infectious diseases, RVF's potentially severe impact on human health, combined with its high mortality for domestic livestock, have made it a priority for global control and prevention.

There are obvious limitations to our study. The susceptibility of $O$. virginianus to RVF infection is unknown, as is its likely morbidity or mortality from infection. Wild African ungulates appear resistant to pathogenic effects of RVF infection, whereas introduced European livestock species are not (Davies, 1975). If deer fail to develop high viraemia, they may prove to be an unsuitable amplifying host for transmission. Conversely, if they suffer high mortality from RVF infection, decimation of herd size may rapidly serve to end local transmission (Piesman, 2006). Our deer census data reflect only one period of deer localization during the year, and a different animal distribution during the peak mosquito season in sum- 
mer may be likely. The arbitrary aggregation of mosquito data by calendar month used in our analysis may obscure the potentially earlier time periods in which a transition in spatial mosquito density occurs. Also, our analysis is based on historical data without continued monitoring and accurate forecasting of abundance based on weather and other local factors, implementation of preventative vector control measures is likely to occur only after mosquito populations have reached critical levels. Finally, because of lack of cross-county deer data and of mosquito data immediately outside the county, our projections of high-risk areas may underestimate risk in border areas.

In Africa, RVF outbreaks can be predicted up to five months in advance using markers of climatic change including sea surface temperature (Linthicum et al., 1987). The dramatic seasonal climate changes that occur in Cuyahoga County are in stark contrast with those of Africa. Duration of severe winter climate conditions (i.e. frost) may have a role in mosquito abundance in the following summer (LaBeaud et al., 2008). Ongoing work to analyze the specific weather patterns of WN virus transmission in Cuyahoga county may elucidate further the risk of other potential arbovirus outbreaks.

The ultimate question is how to address the deer population a potential reservoir for an introduced arbovirus pathogen. Deer control has not proven popular in Lyme disease prevention, where it has been shown that herd size must be drastically reduced to affect disease transmission (Piesman, 2006). Estimates of natural carrying capacity for deer range from 30 up to $75 \mathrm{deer} / \mathrm{km}^{2}$ (78 up to $194 \mathrm{deer} / \mathrm{mi}^{2}$ ) in local habitats (Stoll et al., 1991; O'Brien et al., 2006). Expected culling rates $(42 \%$ in Solon, or a less extensive $28 \%$ (of antlered deer) or $39 \%$ of antlerless deer suggested in other deer control programmes in rural areas (Wasserberg et al., 2009)) would not necessarily be sufficient to prevent transmission in our scenario, because deer fecundity is known to increase as local stocks are reduced. Current density-dependent hunting/harvest rules, combined with parkland refugia, can actually increase the prevalence of deer- associated disease. Within the first transmission season, it will be unclear whether local factors will be able to continue RVF virus transmission from year to year. It would seem advisable, however, to aggressively limit transmission as quickly possible to prevent spread to other regions potentially more favourable to continuing transmission. Ideally, a very active deer vaccination programmme and/or aggressive culling strategies could result in local RVF-related disease extinction if no overwintering mechanisms emerge.

\section{Conclusions}

One hundred years ago, white-tailed deer were nearly extinct in the eastern United States. Since that time, changes in land use and in wildlife management have resulted in a strong resurgence of deer numbers in both rural and peri-urban areas. At present, the potential impact of this large ungulate population in human arbovirus transmission is unknown. However, because of the close overlap of dense human, mosquito, and deer populations in many areas, as demonstrated in this study, there is significant reason for concern that exotic pathogens such as RVF virus could become embedded in urban and peri-urban deer habitat if such viruses get introduced into the North American ecosystems. Future zoonosis research in the US and Canadian special pathogens programmes should focus specifically on deer susceptibility to RVF virus and related phleboviruses, and on the infected deer's capacity to infect North American mosquitoes (that are known to be competent vectors) during the viremic phase of its illness. In addition, in terms of broader public health benefits, it will be useful to find additional means for control of mosquito and deer populations that will prove both safe and acceptable to the general public.

\section{Acknowledgements}

We would like to thank Ann Holstein of Kelvin Smith Library/CWRU for her assistance with ArcGIS data processing; we also thank Joe Lynch and John McLeod of the Cuyahoga County Board of Health for sharing their county- 
wide mosquito data, and the Solon Public Works Department for sharing their white-tailed deer census data. This research was supported by a National Institutes of Health T-35 Short Term Research Grant to Case Western Reserve University, by the Midwest Research Center of Excellence (RCE) in Biodefense (U54 AI057160) and by grant U01 AI45473-S1 (CHK) from the National Institutes of Health.

\section{References}

Al-Hazmi M, Ayoola EA, Abdurahman M, Banzal S, Ashraf J, El-Bushra A, Hazmi A, Abdullah M, Abbo H, Elamin A, Al-Sammani el T, Gadour M, Menon C, Hamza M, Rahim I, Hafez M, Jambavalikar M, Arishi H, Aqeel A, 2003. Epidemic Rift Valley fever in Saudi Arabia: a clinical study of severe illness in humans. Clin Infect Dis 36, 245-252.

Allison AB, Goekjian VH, Potgieter AC, Wilson WC, Johnson DJ, Mertens PP, Stallknecht DE, 2010. Detection of a novel reassortant epizootic hemorrhagic disease virus (EHDV) in the USA containing RNA segments derived from both exotic (EHDV-6)and endemic (EHDV-2) serotypes. J Gen Virol 91, 430-439.

Apperson CS, Hassan HK, Harrison BA, Savage HM, Aspen SE, Farajollahi A, Crans W, Daniels TJ, Falco RC, Benedict M, Anderson M, McMillen L, Unnasch TR, 2004. Host feeding patterns of established and potential mosquito vectors of West Nile virus in the eastern United States. Vector Borne Zoonotic Dis 4, 71-82.

Balkhy HH, Memish ZA, 2003. Rift Valley fever: an uninvited zoonosis in the Arabian peninsula. Int J Antimicrob Agents 21, 153-177.

Bengis RG, Leighton FA, Fischer JR, Artois M, Morner T, Tate CM, 2004. The role of wildlife in emerging and reemerging zoonoses. Rev Sci Tech 23, 497-511.

Brault AC, 2009. Changing patterns of West Nile virus transmission: altered vector competence and host susceptibility. Vet Res 40, 43.

Daubney R, Hudson JR, Garnham PC, 1931. Enzootic hepatitis or Rift Valley fever: an undescribed virus disease of sheep, cattle and man from East Africa. J Pathol Bacteriol 34, 545-579.

Davies FG, 1975. Observations on the epidemiology of Rift Valley fever in Kenya. J Hygiene 75, 219-230.
Davies FG, Linthicum KJ, James AD, 1985. Rainfall and epizootic Rift Valley fever. Bull World Health Organ 63, 941943.

Deplazes P, Hegglin D, Gloor S, Romig T, 2004. Wilderness in the city: the urbanization of Echinococcus multilocularis. Trends Parasitol 20, 77-84.

Evans A, Gakuya F, Paweska JT, Rostal M, Akoolo L, Van Vuren PJ, Manyibe T, Macharia JM, Ksiazek TG, Feikin DR, Breiman RF, Kariuki NM, 2008. Prevalence of antibodies against Rift Valley fever virus in Kenyan wildlife. Epidemiol Infect 136, 1261-1269.

Flick R, Bouloy M, 2005. Rift Valley fever virus. Curr Mol Med 5, 827-834.

Fortin M-J, Drapeau P, 1995. Delineation of ecological boundaries: comparison of approaches and significance tests. OIKOS 72, 323-332.

Hamer GL, Kitron UD, Goldberg TL, Brawn JD, Loss SR, Ruiz MO, Hayes DB, Walker ED, 2009. Host selection by Culex pipiens mosquitoes and West Nile virus amplification. Am J Trop Med Hyg 80, 268-278.

Hoen AG, Rollend LG, Papero MA, Carroll JF, Daniels TJ, Mather TN, Schulze TL, Stafford KC, Fish D, 2009. Effects of tick control by acaricide self-treatment of white-tailed deer on host-seeking tick infection prevalence and entomologic risk for Ixodes scapularis-borne pathogens. Vector Borne Zoonotic Dis 9, 431-438.

Huang S, Hamer GL, Molaei G, Walker ED, Goldberg TL, Kitron UD, Andreadis TG, 2009. Genetic variation associated with mammalian feeding in Culex pipiens from a West Nile virus epidemic region in Chicago, Illinois. Vector Borne Zoonotic Dis 9, 637-642.

Iverson AL, Iverson LR, 1999. Spatial and temporal trends of deer harvest and deer-vehicle accidents in Ohio. Ohio J Sci 99, 84-94.

Kahlon SS, Peters CJ, LeDuc J, Muchiri E, Muiruri S, Njenga MK, Breiman RF, White AC, King CH, 2010. Severe Rift Valley fever may present with a characteristic clinical syndrome. Am J Trop Med Hyg 82, 371-375.

Ksiazek TG, Jouan A, Meegan JM, Le Guenno B, Wilson ML, Peters CJ, Digoutte JP, Guillaud M, Merzoug NO, Touray EM, 1989. Rift Valley fever among domestic animals in the recent West African outbreak. Res Virol 140, 67-77.

LaBeaud AD, Gorman AM, Koonce J, Kippes C, McLeod J, 
Lynch J, Gallagher T, King CH, Mandalakas AM, 2008. Rapid GIS-based profiling of West Nile virus transmission: defining environmental factors associated with an urbansuburban outbreak in Northeast Ohio, USA. Geospat Health 2, 215-225.

Laughlin LW, Meegan JM, Strausbaugh LJ, 1979. Epidemic Rift Valley fever in Egypt: observations of the spectrum of human illness. Trans R Soc Trop Med Hyg 73, 630-633.

Linthicum KJ, Anyamba A, Tucker CJ, Kelley PW, Myers MF, Peters CJ, 1999. Climate and satellite indicators to forecast Rift Valley fever epidemics in Kenya. Science 285, 397-400.

Linthicum KJ, Bailey CL, Davies FG, Tucker CJ, 1987. Detection of Rift Valley fever viral activity in Kenya by satellite remote sensing imagery. Science 235, 1656-1659.

Linthicum KJ, Davies FG, Kairo A, Bailey CL, 1985. Rift Valley fever virus (family Bunyaviridae, genus Phlebovirus). Isolations from Diptera collected during an inter-epizootic period in Kenya. J Hyg (Lond) 95, 197-209.

Logan TM, Davies FG, Linthicum KJ, Ksiazek TG, 1992. Rift Valley fever antibody in human sera collected after an outbreak in domestic animals in Kenya. Trans R Soc Trop Med Hyg 86, 202-203.

Manangan JS, Schweitzer SH, Nibbelink N, Yabsley MJ, Gibbs SE, Wimberly MC, 2007. Habitat factors influencing distributions of Anaplasma phagocytophilum and Ehrlichia chaffeensis in the Mississippi Alluvial Valley. Vector Borne Zoonotic Dis 7, 563-573.

Mandalakas AM, Kippes C, Sedransk J, Kile JR, Garg A, McLeod J, Berry RL, Marfin AA, 2005. West Nile virus epidemic, northeast Ohio, 2002. Emerg Infect Dis 11, 17741777.

Molaei G, Farajollahi A, Armstrong PM, Oliver J, Howard JJ, Andreadis TG, 2009a. Identification of bloodmeals in Anopheles quadrimaculatus and Anopheles punctipennis from eastern equine encephalitis virus foci in northeastern U.S.A. Med Vet Entomol 23, 350-356.

Molaei G, Farajollahi A, Scott JJ, Gaugler R, Andreadis TG, 2009b. Human bloodfeeding by the recently introduced mosquito, Aedes japonicus japonicus, and public health implications. J Am Mosq Control Assoc 25, 210-214.

Muturi EJ, Muriu S, Shililu J, Mwangangi JM, Jacob BG, Mbogo C, Githure J, Novak RJ, 2008. Blood-feeding patterns of Culex quinquefasciatus and other culicines and implications for disease transmission in Mwea rice scheme, Kenya. Parasitol Res 102, 1329-1335.

Naugle DE, Jenks JA, Kernohan BJ, 1996. Use of thermal infrared sensing to estimate density of white-tailed deer. Wildlife Soc Bull 24, 37-43.

O'Brien DJ, Schmitt SM, Fitzgerald SD, Berry DE, Hickling GJ, 2006. Managing the wildlife reservoir of Mycobacterium bovis: the Michigan, USA, experience. Vet Microbiol 112, 313-323.

Piesman J, 2006. Strategies for reducing the risk of Lyme borreliosis in North America. Int J Med Microbiol 296, 17-22.

Ruiz MO, Tedesco C, McTighe TJ, Austin C, Kitron U, 2004. Environmental and social determinants of human risk during a West Nile virus outbreak in the greater Chicago area, 2002. Int J Health Geogr 3, 8.

Shafer-Nolan AL, 1997. The science and politics of deer overabundance at Cuyahoga Valley National Recreation Area, Ohio. Wildlife Soc Bull 25, 457-461.

Stoll RJ, McClain MW, Clem JC, Plageman T, 1991. Accuracy of helicopter counts of white-tailed deer in western Ohio farmland. Wildlife Soc Bull 19, 309-314.

Turell MJ, Dohm DJ, Mores CN, Terracina L, Wallette DL, Hribar LJ, Pecor JE, Blow JA, 2008. Potential for North American mosquitoes to transmit Rift Valley fever virus. J Am Mosq Control Assoc 24, 502-507.

Wasserberg G, Osnas EE, Rolley RE, Samuel MD, 2009. Host culling as an adaptive management tool for chronic wasting disease in white-tailed deer: a modelling study. J Appl Ecol 46, 457-466.

Weaver SC, Reisen WK, 2010. Present and future arboviral threats. Antiviral Res 85, 328-345.

Wilson ML, Chapman LE, Hall DB, Dykstra EA, Ba K, Zeller HG, Traore-Lamizana M, Hervy JP, Linthicum KJ, Peters CJ, 1994. Rift Valley fever in rural northern Senegal: human risk factors and potential vectors. Am J Trop Med Hyg 50, 663-675.

Woods CW, Karpati AM, Grein T, McCarthy N, Gaturuku P, Muchiri E, Dunster L, Henderson A, Khan AS, Swanepoel R, Bonmarin I, Martin L, Mann P, Smoak BL, Ryan M, Ksiazek TG, Arthur RR, Ndikuyeze A, Agata NN, Peters CJ, WHO Hemorrhagic Fever Task Force, 2002. An outbreak of Rift Valley fever in northeastern Kenya, 1997-98. Emerg Infect Dis 8, 138-144. 